\title{
Feeding habits of the alien brook trout Salvelinus fontinalis and the native brown trout Salmo trutta in Czech mountain streams
}

\author{
Petra Horká $^{1, *}$, Olga Sychrová ${ }^{2}$, Pavel Horký ${ }^{3}$, Ondřej Slavík ${ }^{3}$, Miroslav Švátora ${ }^{2}$ and Adam Petrusek ${ }^{4}$ \\ ${ }^{1}$ Institute for Environmental Studies, Faculty of Science, Charles University, Benátská 2, 12801 Prague 2, Czech Republic \\ ${ }^{2}$ Department of Zoology, Faculty of Science, Charles University, Viničná 7, 12844 Prague 2, Czech Republic \\ ${ }^{3}$ Department of Zoology and Fisheries, Faculty of Agrobiology, Food and Natural Resources, Czech University of Life Sciences Prague, \\ Kamýcká 129, 16500 Prague 6, Czech Republic \\ ${ }^{4}$ Department of Ecology, Faculty of Science, Charles University, Viničná 7, 12844 Prague 2, Czech Republic
}

\begin{abstract}
Quantifying patterns of prey resource use is fundamental to identify mechanisms enabling the coexistence of related fish species. Trophic interactions between the native brown trout, Salmo trutta, and the introduced brook trout, Salvelinus fontinalis, were studied monthly from May to October in three mountain streams in Central Europe (Czech Republic). To evaluate whether the feeding habits differ between separated and coexisting populations of these species, one locality where both species coexist, and two allopatric populations of either species were studied. Across the study period, the mean stomach fullness of fish varied, being highest in spring and declining through autumn. The diet overlap (Schoener's overlap index) between the species increased through the studied season (from 54.5\% in July to $81.5 \%$ in October). In allopatry, both species had nearly the same feeding habits. However, in sympatry, brook trout consumed higher proportion of terrestrial invertebrates, while brown trout showed no changes either in the proportions of aquatic and terrestrial prey utilized or in the selectivity for prey categories in comparison to allopatric conditions. The dietary shift observed for brook trout, but not for brown trout, suggests that brown trout is a stronger competitor in the studied sympatric locality, leading the brook trout to change its feeding habits to reduce interspecific competition.
\end{abstract}

Keywords: feeding behaviour / salmonids / coexistence / overlap / diet

Résumé - Habitudes alimentaires de l'omble de fontaine exogène Salvelinus fontinalis et de la truite indigène Salmo trutta dans les ruisseaux de montagne tchèques. La quantification des modes d'utilisation des ressources est essentielle pour identifier les mécanismes permettant la coexistence d'espèces de poissons proches. Les interactions trophiques entre la truite brune indigène, Salmo trutta et l'omble de fontaine introduit, Salvelinus fontinalis, ont été étudiées mensuellement de mai à octobre dans trois cours d'eau de montagne en Europe centrale (République tchèque). Pour évaluer si les habitudes alimentaires diffèrent entre les populations séparées et coexistantes de ces espèces, une localité où les deux espèces coexistent et deux populations allopatriques de l'une ou l'autre espèce ont été étudiées. Au cours de la période étudiée, la plénitude gastrique moyenne des poissons a varié, étant la plus élevée au printemps et diminuant à l'automne. Le chevauchement du régime (indice de chevauchement de Schoener) entre les espèces a augmenté au cours de la saison étudiée (de 54,5\% en juillet à $81,5 \%$ en octobre). En allopatrie, les deux espèces avaient pratiquement les mêmes habitudes alimentaires. Cependant, en sympatrie, l'omble de fontaine a consommé une proportion plus élevée d'invertébrés terrestres, tandis que la truite brune n'a montré aucun changement ni dans les proportions de proies aquatiques et terrestres utilisées ni dans la sélectivité pour les catégories de proies en comparaison aux conditions allopatriques. Le changement de régime alimentaire observé pour l'omble de fontaine, mais pas pour la truite brune, suggère que la truite brune est un concurrent plus fort dans la localité sympatrique étudiée, ce qui amène l'omble de fontaine à changer ses habitudes alimentaires pour réduire la compétition interspécifique.

Mots-clés : comportement alimentaire / salmonidés / coexistence / chevauchement / régime

\footnotetext{
* Corresponding author: petra.horka@natur. cuni.cz
} 


\section{Introduction}

During the last two centuries, introduction of non-native species has led to changes in the structure of fish communities worldwide (Morgan et al., 2004). Salmonids, particularly brown trout, Salmo trutta Linnaeus, 1758, brook trout Salvelinus fontinalis (Mitchill, 1814), and rainbow trout, Oncorhynchus mykiss (Walbaum, 1792), are taxa whose introduction has led to the disruption of the original distribution patterns of native fish populations in streams in many regions (e.g., Takami and Aoyama, 1999; Dunham et al., 2002; Peterson and Fausch, 2003; Woodford et al., 2005).

Apart from factors such as predation and hybridization, by which alien salmonids affect populations of native species, interspecific competition is of great importance (Kitano et al., 1994; Nakano et al., 1998; Taniguchi et al., 2002; Finlayson et al., 2005). Competition for limited resources is more likely to occur in populations of species that are not naturally sympatric (Hearn, 1987). An important mechanism allowing the species to reduce competition is food resource partitioning, including both spatial and temporal differentiation and changes in feeding habits (Pianka 1969; Schoener, 1974). Indeed, it has been formerly shown that the interaction between related salmonid species magnifies the differences in the use of habitat or food resources (Blanchet et al., 2007; Dineen et al., 2007; Sánchez-Hernández et al., 2016).

In many European streams, the native brown trout was replaced by the non-native brook trout, which was introduced to the mountain regions throughout Europe as an acid-tolerant species or for recreational angling (Delacoste et al., 1997; Uiblein et al., 2001). Although brook trout populations are endangered by brown trout in areas where the former species is indigenous (north-eastern North America; Fausch and White, 1981), brook trout became successfully established in many European streams formerly known to hold only populations of brown trout (Holčík, 1991; Lusk et al., 2010). This situation raises the question of resource competition between these species and possible outcomes of such interactions.

Studying the feeding behaviour between native and exotic species allows better understanding of the competitive interactions in fish communities where non-native salmonids were introduced. To date, several studies have focused on the feeding habits of brown trout and brook trout separately (e.g., Sánchez-Hernández and Cobo, 2016; Tiberti et al., 2016), or with other related species (Mookerji et al., 2004; McHugh et al., 2008). However, knowledge of the trophic ecology of brown trout and brook trout inhabiting the same streams still has significant gaps, although some studies do exist. In this sense, trophic interactions between native brown trout and introduced brook trout have been previously examined by Cucherousset et al. (2007), who observed brown trout to shift its diet towards terrestrial invertebrates in sympatry with brook trout in a French mountain stream. In contrast, no niche partitioning of food resources was observed between these species in New Zealand where both species are alien (Fechney, 1988). Some other studies described the coexistence of brown trout or brook trout with other related taxa. For example, in coexistence with Atlantic salmon Salmo salar Linnaeus, 1758, brown trout was shown to feed more on terrestrial resources
(Dineen et al., 2007; Sánchez-Hernández et al., 2013), while brook trout similarly increased intake of terrestrial invertebrate prey and exhibited wider diet breadth (Mookerji et al., 2004). Such results suggest that the partitioning of food resources is an important mechanism enabling the coexistence of related salmonids.

The objective of our study was to examine trophic interaction between native brown trout and alien brook trout in Czech mountain streams. Specifically, we tested whether brook trout can alter feeding habits of brown trout (or vice versa) at a site where populations of both species coexist. We presumed that competition can alter feeding habits of the subdominant species in the presence of a stronger competitor. The abundance and utilization of aquatic and terrestrial invertebrates were compared in three mountain streams of the Jizera Mountains (Czech Republic), including one locality where both species coexist, and two allopatric populations of either species.

\section{Material and methods}

\subsection{Study area}

The study was conducted in two streams where brown trout and brook trout occurred separately (brown trout: Malý Štolpich, $50^{\circ} 52^{\prime} \mathrm{N} ; 15^{\circ} 10^{\prime} \mathrm{E} ; 365 \mathrm{~m}$ a.s.l.; brook trout: Černá Nisa, $50^{\circ} 50^{\prime} \mathrm{N} ; 15^{\circ} 09^{\prime} \mathrm{E} ; 774 \mathrm{~m}$ a.s.l.) and at one locality where both species lived together (Malá Jeřice, $50^{\circ} 51^{\prime} \mathrm{N} ; 15^{\circ} 05^{\prime} \mathrm{E}$; $385 \mathrm{~m}$ a.s.1.). All three streams are located in the Jizera Mountains, northern Czech Republic. The localities are second-order mountain streams, with pools separated by riffles and stretches with slow-flowing current. One reach approximately $120 \mathrm{~m}$ long, from which fish and invertebrate samples were collected, was selected for each stream. The stream width at the sampled reaches ranged from 2 to $5 \mathrm{~m}$. The streambed was in all three cases comprised of shallow riffles with a gravel bottom interspersed with deeper pools where plant detritus accumulated. The flow regime can be characterized as pluvio-nival; during the study the flow varied from 0.05 to $0.135 \mathrm{~m}^{3} \mathrm{~s}^{-1}$. Riparian vegetation consisted mostly of European hazel Corylus avellana L., black alder Alnus glutinosa (L.), and Norway spruce Picea abies (L.). No other fish or vertebrate species occurred in the streams, with the exception of brook lamprey Lampetra planeri (Bloch, 1784) rarely observed with brown trout in Malý Štolpich. During the study year, no fishery management (e.g., stocking of hatchery fish) was performed at the studied localities.

\subsection{Sampling and sample processing}

Samples of fish and aquatic and terrestrial invertebrates were collected monthly from May to October 2004 to evaluate seasonal changes in invertebrate composition and fish diet. Fish were caught by electrofishing using a two-pass depletion method (Seber and Le Cren, 1967) to ensure representative estimates of fish abundance at each site. The densities of each species at the allopatric localities were comparable, 0.26 ind. $\mathrm{m}^{-2}$ for both brown trout and brook trout. At the sympatric locality, the densities were 0.35 ind. $\mathrm{m}^{-2}$ for brown trout and 0.16 ind. $\mathrm{m}^{-2}$ for brook trout. 
P. Horká et al.: Knowl. Manag. Aquat. Ecosyst. 2017, 418, 6

Table 1. Summary of mixed models analysis for the four models (M I-M IV). Num DF - numerator DF, Den DF - denumerator DF.

\begin{tabular}{lcccc}
\hline Effect & Num DF & Den DF & $F$ & $P$-value \\
\hline M I (fish length) & 1 & 14 & 0.02 & 0.8787 \\
M II (fish weight) & 1 & 114 & 0.00 & 0.9808 \\
$\begin{array}{l}\text { M III (number of prey categories) } \\
\text { locality (fish species * type of prey) }\end{array}$ & 4 & 8871 & 4.87 & 0.0001 \\
$\begin{array}{l}\text { M IV (prey selectivity) } \\
\text { locality (aquatic prey taxon* fish species) }\end{array}$ & 53 & 2739 & 48.35 \\
\hline
\end{tabular}

A total of 235 fish individuals (i.e., 116 specimens of brown trout and 119 specimens of brook trout) were selected for analysis of fish stomach contents. Preferentially, individuals of $2+$ and $3+$ age classes with a similar length distribution were sampled (and thus neither length nor weight of examined fish differed significantly among localities or species; Tab. 1).

After collection, fish were anesthetized by clove oil, weighed to the nearest $0.01 \mathrm{~g}$, and measured for total length $\left(L_{\mathrm{T}}\right)$ to the nearest $0.1 \mathrm{~cm}$. At the allopatric localities, standard body lengths of the analysed fish were $108.4 \pm 37.5 \mathrm{~mm}$ $($ mean $\pm \mathrm{SD}$ ) for brown trout and 109.2 $\pm 52.2 \mathrm{~mm}$ for brook trout; at sympatry, the body lengths of brown trout and brook trout were $107.3 \pm 37.2$ and $103.8 \pm 37.3 \mathrm{~mm}$, respectively.

Fish stomachs were preserved in $80 \%$ ethanol and their contents later examined in the laboratory under a stereomicroscope. For each stomach, the number of prey items was counted and identified to the lowest possible taxonomic level (usually family or order due to fragmentation of prey). The use of animals complied with national animal welfare legislation (law no. 246/1992), and was approved by the ethical committee of the Faculty of Science, Charles University, Prague.

To quantify food availability, aquatic and terrestrial invertebrates were collected from the streams immediately before the fish sampling. Aquatic invertebrates (benthos) were sampled by the kick-sampling method (Frost, 1971), using a net with a $0.5 \mathrm{~mm}$ mesh size and the same sampling effort. Three types of substrata (stones, gravel, and finer sediment/ plant detritus) were sampled for $20 \mathrm{~s}$ at five different points at each study site, from the same-sized area of the stream bottom. Samples were preserved soon after collection and stored in $70 \%$ ethanol. Collected invertebrates were identified (usually to genera or species) and enumerated; replicates from each type of habitat (stream substrate) were pooled together. To take into account the different proportions of the three types of bottom habitat in the studied streams, we estimated the area of each habitat in the sampled reaches. The average food supply at studied localities was then calculated as the weighted average of the number of individuals collected from the three substrates, the weights being the proportions of the particular substrate in the sampled reach.

Terrestrial invertebrates were collected at all sampling dates except May using drift nets. The nets for collection of drifting invertebrates (mouth area $1 \mathrm{~m}^{2}$, length $1.5 \mathrm{~m}$, mesh size $0.3 \mathrm{~mm}$ ) were placed in the stream before sampling of aquatic invertebrates, and each drift collection consisted of three individual samples. Drifting invertebrates were collected for $30 \mathrm{~min}$, between 11.00 and 13.00 hours for each sampling date. The bottom of the nets was $5 \mathrm{~cm}$ above the bottom substrate, and the top of the nets extended above the water surface. Samples were preserved in the field with $70 \%$ ethanol. The collected invertebrates were identified to the lowest taxonomic level (usually to genera or families) and enumerated. Data on food supply (both benthos and drift) are provided in the Electronic Supplementary Material (Tabs. S1 and $\mathrm{S} 2$ ).

Stream discharge was estimated based on in-situ measurements of stream width, and five measures of depth and current using a current meter (Global Flow Probe FP 201, Global Water Instrumentation, Inc., USA) at approximately middepth at each of five sites across the stream. Flow through each net was measured at the net openings at the beginning and end of each sampling period. The abundance of drifting invertebrates was expressed as a number per cubic meter according to Allan and Russek (1985) as follows:

$$
\begin{aligned}
& \text { Number of drifting invertebrates } \\
& =\frac{\text { numbers per net-hour }}{m^{3} \text { filtered per net-hour }}
\end{aligned}
$$

where $\mathrm{m}^{3}$ filtered per net hour is estimated from the net mouth area and current at net mouth. Numbers of aquatic and terrestrial invertebrates present at the site during each sampling occasion ('number of invertebrates') and the number of aquatic and terrestrial prey ingested ('number of prey') were separately standardized to values from 0 to 1 in order to assure their comparability.

To facilitate comparisons among fish of different sizes, a stomach fullness index $\left(\mathrm{SF}_{i} ; \%\right)$ was used as an indicator of differences in feeding intensity over the season. $\mathrm{SF}_{i}$ was quantified separately for every study month (May to October), and calculated as the stomach content weight expressed as a percentage of body weight:

$$
\mathrm{SF}_{i}(\%)=\frac{\text { total stomach content weight }}{\text { total fish weight }} \times 100 \text {. }
$$

The selective index ( $D$; Jacobs, 1974) was used to examine selection for each prey category (focusing on benthic invertebrates) using the formula:

$$
D=(r-p)(r+p-2 r p)^{-1},
$$

where $r$ is the fraction of a given food type in the fish stomachs in each individual and $p$ was the fraction of the same food type in the environment (i.e., the benthos samples). The index varies from -1 to 1 , where values below zero indicate negative selection and above zero positive selection. This index was 
Table 2. Number of prey items and frequency of occurrence of each food category recorded in stomachs of brown trout and brook trout, from Czech streams Malá Jeřice (allopatric brown trout), Černá Nisa (allopatric brook trout) and Malý Štolpich (sympatry). $n$ - total number of stomachs examined; $N$ - total number of prey items in each category; $N(\%)$ - average proportion of each category in the stomachs.

\begin{tabular}{|c|c|c|c|c|c|c|c|c|}
\hline \multirow[t]{3}{*}{ Prey category } & \multicolumn{4}{|c|}{ Brown trout } & \multicolumn{4}{|c|}{ Brook trout } \\
\hline & \multicolumn{2}{|c|}{$\begin{array}{c}\text { Allopatry } \\
n=58\end{array}$} & \multicolumn{2}{|c|}{$\begin{array}{c}\text { Sympatry } \\
n=58\end{array}$} & \multicolumn{2}{|c|}{$\begin{array}{c}\text { Allopatry } \\
n=71\end{array}$} & \multicolumn{2}{|c|}{$\begin{array}{c}\text { Sympatry } \\
n=48\end{array}$} \\
\hline & $N$ & $N(\%)$ & $N$ & $N(\%)$ & $N$ & $N(\%)$ & $N$ & $N(\%)$ \\
\hline \multicolumn{9}{|l|}{ Aquatic } \\
\hline Megaloptera & 1 & 0.1 & - & - & 1 & - & 1 & - \\
\hline Ephemeroptera & 17 & 1.1 & - & - & 18 & 0.8 & 1 & - \\
\hline Plecoptera & 58 & 3.7 & 23 & 1.5 & 208 & 9.2 & 29 & 1.3 \\
\hline Trichoptera & 221 & 13.9 & 251 & 16.6 & 233 & 10.3 & 141 & 6.1 \\
\hline Coleoptera & 3 & 0.2 & 10 & 0.7 & 2 & - & 3 & - \\
\hline Diptera & 619 & 39.0 & 320 & 21.2 & 1128 & 50.0 & 481 & 20.9 \\
\hline Oligochaeta & 2 & 0.1 & - & - & - & - & - & - \\
\hline Hydracarina & - & - & - & - & 1 & - & 81 & 3.5 \\
\hline \multicolumn{9}{|l|}{ Terrestrial } \\
\hline Megaloptera & - & - & 1 & 0.1 & 3 & 0.1 & 4 & 0.2 \\
\hline Trichoptera & 7 & 0.4 & 3 & 0.2 & 8 & 0.4 & 2 & 0.1 \\
\hline Diptera & 97 & 6.1 & 117 & 7.7 & 197 & 8.7 & 161 & 7.0 \\
\hline Hymenoptera & 155 & 9.8 & 225 & 14.9 & 225 & 10.0 & 337 & 14.7 \\
\hline Heteroptera & 10 & 0.6 & 46 & 3.0 & - & - & 126 & 5.5 \\
\hline Coleoptera & 151 & 9.5 & 275 & 18.2 & 121 & 5.4 & 400 & 17.4 \\
\hline Lepidoptera & - & - & 3 & 0.2 & - & - & 6 & 0.3 \\
\hline Dermaptera & - & - & 2 & 0.1 & - & - & 3 & 0.1 \\
\hline Aphidomorpha & 215 & 13.6 & 142 & 9.4 & 51 & 2.3 & 344 & 15.0 \\
\hline Psyllomorpha & 23 & 1.5 & 42 & 2.8 & 2 & 0.1 & 84 & 3.7 \\
\hline Araneida & - & - & 20 & 1.3 & 4 & 0.2 & 9 & 0.4 \\
\hline Auchenorrhyncha & 6 & 0.4 & 32 & 2.1 & 10 & 0.4 & 72 & 3.1 \\
\hline
\end{tabular}

used for comparing localities, considering differences in prey selectivity and prey availability.

We evaluated the fish feeding strategy following Amundsen et al. (1996), where the prey-specific abundance $\left(P_{i}\right)$ is plotted against prey frequency of occurrence $\left(F_{i}\right)$ in the diet of the predator:

$$
\begin{gathered}
F_{i}=\frac{N_{i}}{N}, \\
P_{i}=\frac{\sum S_{i}}{\sum S t_{i}} \times 100,
\end{gathered}
$$

where $P_{i}$ is the prey-specific abundance of prey $i$, defined as the percentage of a prey taxon in all prey categories consumed by those predators in which the actual prey occurs. $N_{i}$ is the number of fish with prey $i$ in their stomach, $N$ is the total number of fish with stomach content, $S_{i}$ is the number of prey $i$ items in fish stomachs, and $S t_{i}$ is the total stomach content, including only those predators with prey $i$ in their stomach. For each locality, $F_{i}$ and $P_{i}$ values averaged over all study months (May to October) were used to create a diagram of feeding tactics (see Results; Amundsen et al., 1996).
The index of Schoener (1970) was used to evaluate the diet overlap of the two studied species in sympatry. The index values were obtained from a comparison (by abundance) between the diets of brown trout and brook trout stomach contents:

$$
C_{x, y}=1-0.5 \sum\left|p_{x, i}-p_{y, i}\right|
$$

where $p_{x, i}$ and $p_{y, i}$ are the estimated proportions by abundance of prey $i$ in the diets of species $x$ and $y$, respectively (the percentage by abundance of prey categories in Tab. 2). The index ranges from 0 , which indicates no dietary overlap, to a maximum overlap of 1 , when all prey categories are found in equal proportions. Index values higher than 0.60 were considered as an indicator of a high dietary overlap (Langton, 1982). Dietary overlap values were complemented with stomach fullness index $\left(\mathrm{SF}_{i} ; \%\right)$ and compared across months for the species at the sympatric locality Malá Jerrice.

\subsection{Statistical analysis}

Associations among the variables were tested using mixed model analyses with a PROC MIXED (SAS 9.1 
software). A mixed model is a generalization of standard models, permitting the data to exhibit correlation and nonconstant variability (Littell et al., 1996). The 'fixed effects' are associated with standard explanatory variables, while random effects are additional variables assumed to impact data variability as covariance parameters. We assumed that fish individuality can influence its food preference and consequently weight with respect to its position in the hierarchy and related personality aspects (e.g., Conrad et al., 2011). Similarly, food supply may change across seasons (Lagarrigue et al., 2002). Therefore we included individual fish and month as random effects.

Separate models were applied for the following dependent variables: fish length (M I), fish weight (M II), number of prey (M III) and selectivity for prey category (M IV). Prior analysis, prey taxa were grouped into 'type of prey' (aquatic, terrestrial) and 'aquatic prey taxon' (15 classes). Data were transformed (square root or log $(x+1))$ to meet normality and homoscedasticity requirements before analyses when needed. The fixed effects included 'fish species' ( 2 classes - brown trout, brook trout) and 'locality' (3 classes - Malá Jeřice, Malý Štolpich, Černá Nisa) for all models (M I-M IV); 'type of prey' (2 classes aquatic, terrestrial) for M III; 'aquatic prey taxon' (15 classes, e.g., Chironomidae) and 'months' (6 classes; one for each month and from May to October) for M IV. The significance of each fixed effect (including interactions) in the mixed models was assessed by the $F$-test with sequential dropping of the least significant effect, starting with a full model. Fixed effects and their interactions that were nonsignificant are not discussed further.

In unbalanced designs with more than one effect, the arithmetic mean for a group may not accurately reflect the response for that group, since it does not take other effects into account. Therefore we used least-squares means (LSM) instead. LSM are, in effect, within group means appropriately adjusted for the other effects in the model. LSM (henceforth referred to as 'adjusted means') were computed for each class, and differences between classes were tested by $t$-tests. For multiple comparisons we used the Tukey-Kramer adjustment. The degrees of freedom were calculated using the KenwardRoger method (Kenward and Roger, 1997).

\section{Results}

\subsection{Dietary composition}

Forty prey categories, mostly of aquatic and terrestrial insects, were identified in the diet of fish at studied localities (Tab. 2, see Tab. S3 for monthly diet composition). In both brook and brown trout, the aquatic fraction of the ingested food consisted mainly of trichopteran and chironomid larvae. Small hymenopterans, coleopterans, and aphids belonged to the most common terrestrial prey. Other categories frequently occurring in fish diet were simuliids, plecopterans, and water mites. Coleopterans (aquatic fraction), adult trichopterans, dipterans, and psyllids (terrestrial fraction) belonged among the categories with lower frequency of occurrence in fish diet. All other potential prey categories were only rarely found in the fish diet or completely absent. Piscivory behaviour was observed for three individuals (two in sympatric and one in allopatric conditions). Additionally, two small lizards were found in the stomachs of brook trout in Malá Jeřice (Tab. S3 in Electronic Supplementary Material).

\subsection{Utilization of aquatic and terrestrial prey}

The number of prey categories ingested was significantly influenced by the locality nested within interaction between fish species and type of prey (M III; Tab. 1). The diets of both species were composed of similar proportions of aquatic and terrestrial prey in allopatry, while they differed in sympatry. Specifically, the brown trout stomachs contained similar proportions of aquatic and terrestrial invertebrates at both localities. In contrast, brook trout in coexistence with brown trout showed higher proportion of terrestrial prey in their diet than in allopatry (Fig. 1).

In allopatry, both species had nearly the same prey composition (Fig. 2). However, chironomids were consumed by brook trout more than by brown trout, and aphids and adult coleopterans were consumed by brown trout significantly more than by brook trout. In sympatry, brook trout consumed significantly more chironomid larvae and aphids than brown trout.

\subsection{Selectivity for prey categories and feeding strategy}

The majority of negative selectivity indices suggest that most taxa were not preyed upon proportionally to their abundance in the environment (Fig. 3). The main positively selected categories were chironomid and trichopteran larvae. The final model for prey selectivity (M IV; Tab. 1) contained the fixed factor 'locality' nested within the interaction between prey order and fish species. The selectivity for categories of aquatic prey between localities differed only for brook trout (Fig. 3). This species preferred adult coleopterans more at sympatric than in allopatric conditions. On the contrary, preference of brook trout for trichopteran larvae was significantly higher at allopatry. No significant differences in feeding selectivity were found within brown trout populations, as the species at both localities preferred mainly trichopteran larvae. Food selectivity for other prey categories of aquatic invertebrates was low in both species.

The feeding strategy of both fish species may be characterized as mixed, with varying degrees of specialization and generalization on different prey categories (Fig. 4). Overall, both species showed a generalist strategy, but with some specialization on chironomids (brook trout) and trichopterans (brown trout).

During the study period, the mean stomach fullness of fish varied, being highest in spring (May) and declining towards autumn (October). Overall, stomach content averaged $8.6 \%$ of their body weight of brown trout, and $9.1 \%$ of brook trout (Tab. S4; Fig. 5). The values for diet overlap between the two species had an opposite trend; the diet overlap increased through the observed season, being highest in autumn $(54.5 \%$ in June $-81.5 \%$ in October). 
P. Horká et al.: Knowl. Manag. Aquat. Ecosyst. 2017, 418, 6

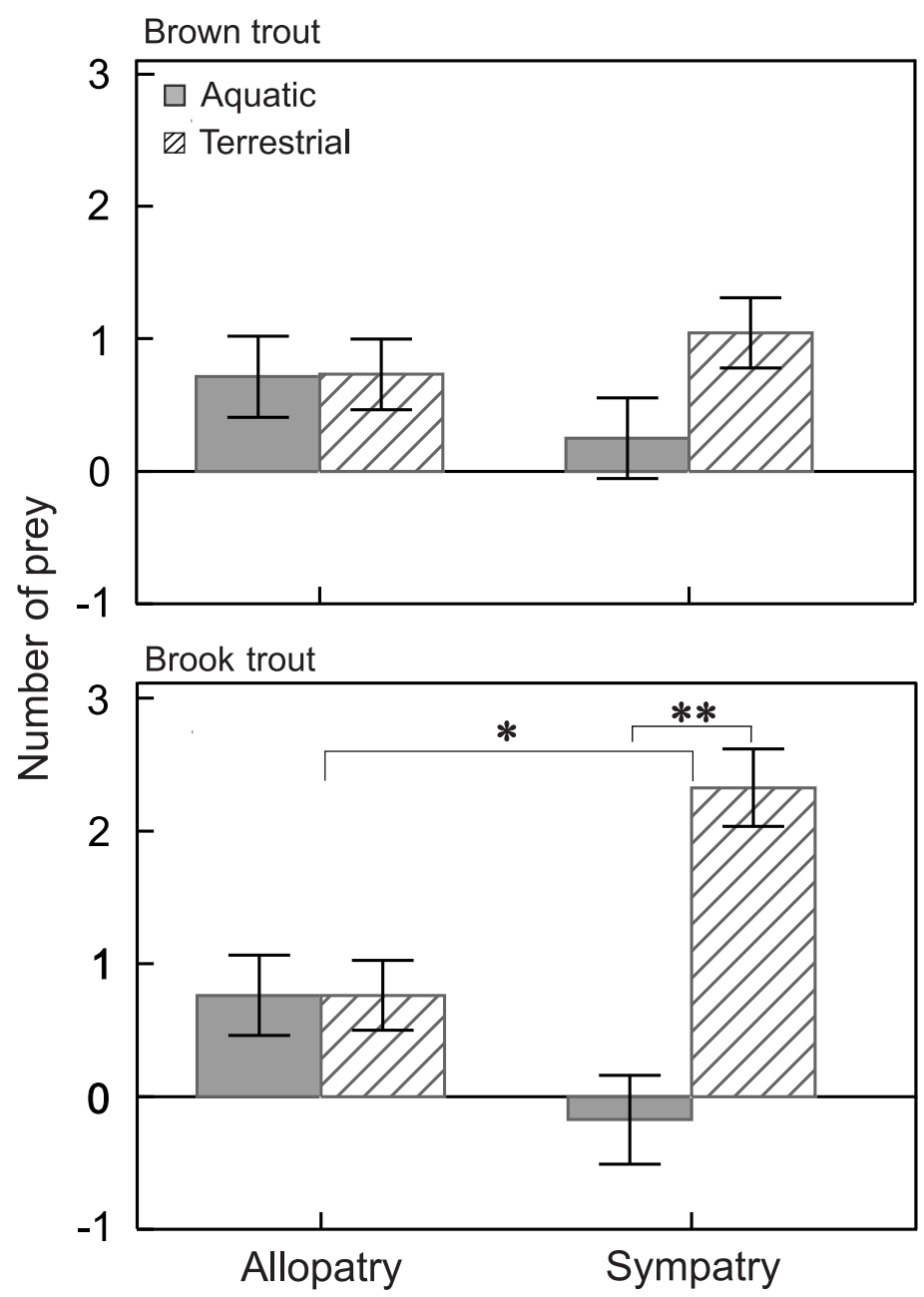

Fig. 1. Number of aquatic and terrestrial prey (adjusted mean \pm s.e.) found in the stomachs of sympatric and allopatric populations of (a) brown trout and (b) brook trout from the streams Malá Jeřice, Černá Nisa, and Malý Štolpich, located in Jizera Mts., Czech Republic. Brackets with asterisks indicate significant difference between groups $(* P<0.05 ; * * P<0.01)$.

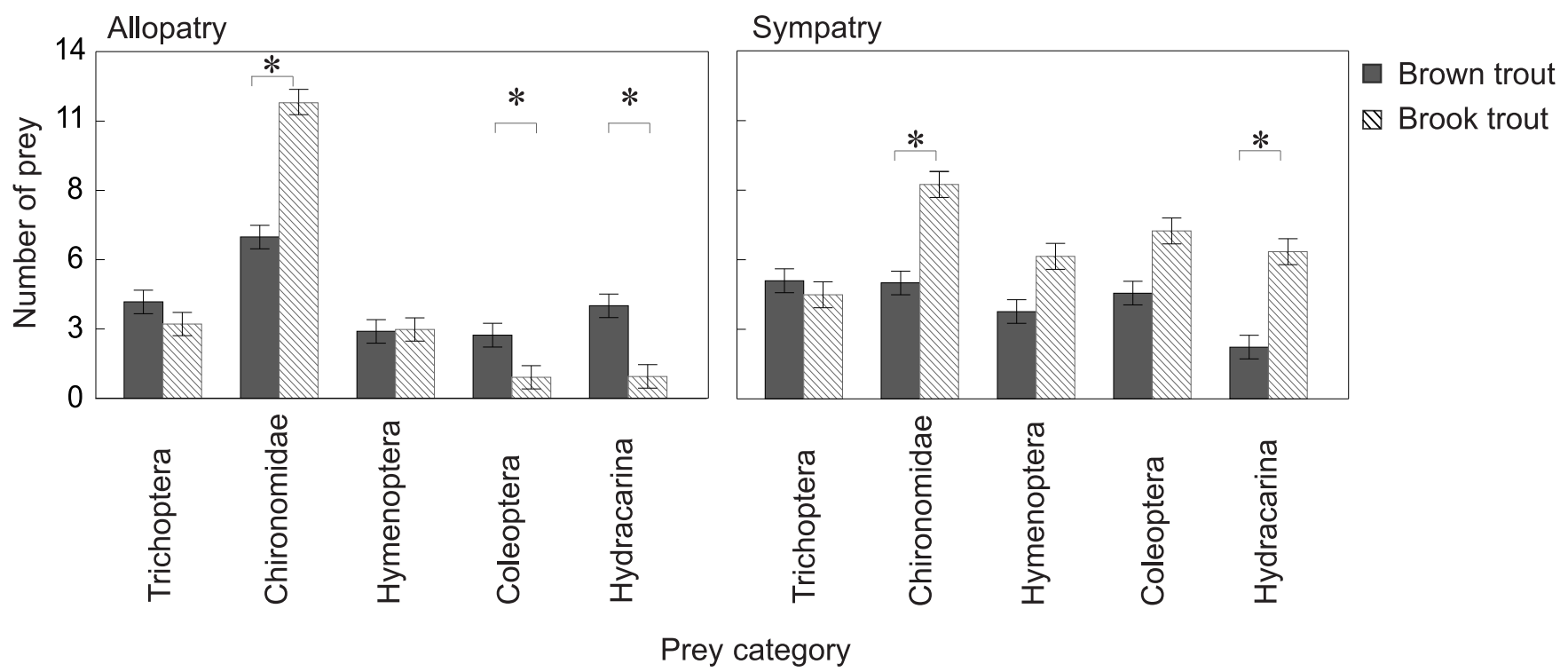

Fig. 2. Number of prey for each analyzed food category (adjusted mean \pm s.e.) found in the stomachs of brown trout and brook trout at the studied allopatric and sympatric localities. Only prey categories whose percent composition made up at least $10 \%$ of the stomach content are shown. Brackets with asterisks indicate significant differences between groups $(* P<0.05)$. 


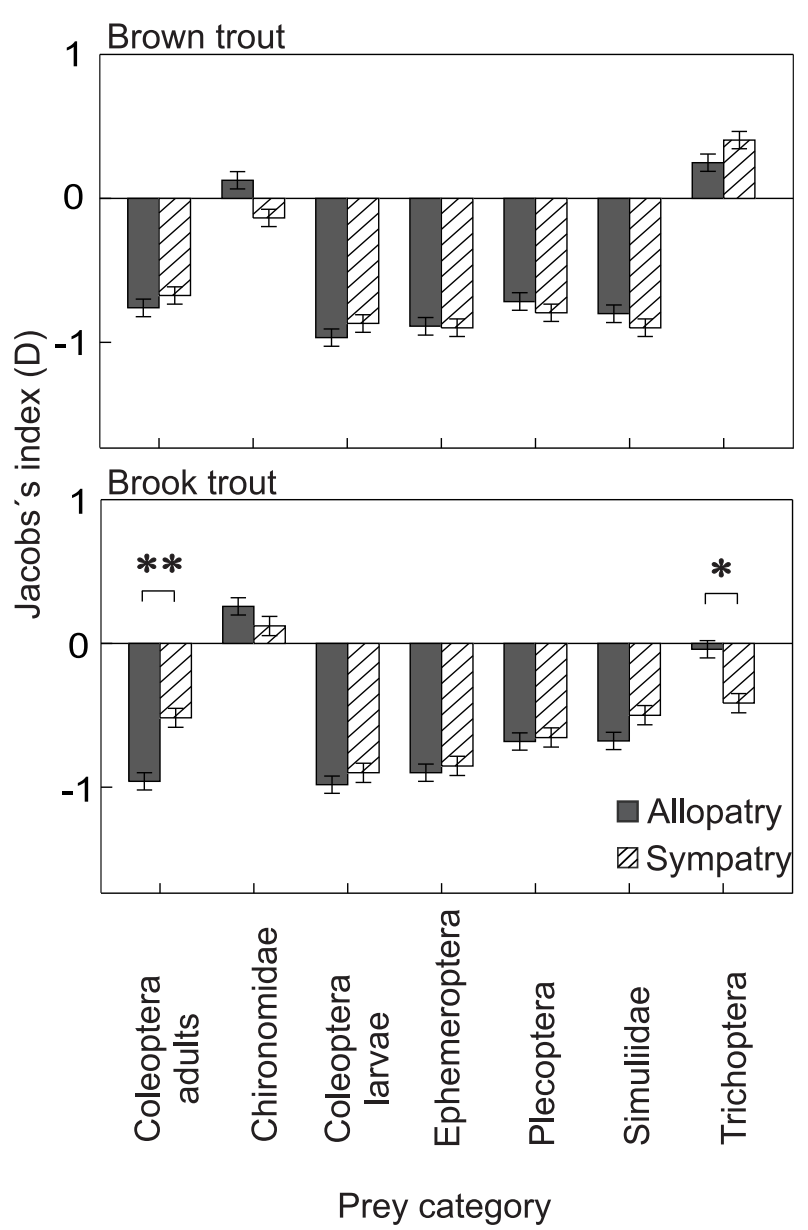

Fig. 3. Adjusted mean and standard error of the selectivity index ( $D$; according to Jacobs, 1974) for aquatic prey in allopatric and sympatric populations of brown trout and brook trout. Positive $D$ values indicate preference and negative values avoidance. Brackets with asterisks indicate significant differences between allopatric and sympatric populations $(* P<0.05 ; * * P<0.01)$.

\section{Discussion}

Our study has shown that in the studied Czech streams, the diet of brown trout and brook trout was remarkably similar at the allopatric localities. However, a shift towards the utilization of terrestrial prey was found in brook trout in sympatry, but not in brown trout.

Diets containing more terrestrial invertebrates in one of the two coexisting species have been reported by several studies on related species of salmonids (Coghlan et al., 2007; McHugh et al., 2008; Wilson et al., 2014). Such shifts may be caused by differences in prey utilization, as well as by changes in habitat use when the dominant species outcompetes subordinates from favourable feeding positions (Blanchet et al., 2007). Interestingly, in contrast to our study, shift in the diet of native brown trout due to a presence of introduced brook trout was observed by Cucherousset et al. (2007) in France. The observed changes in $\delta^{13} \mathrm{Ca} \delta^{15} \mathrm{~N}$ values in native brown trout indicated a higher proportion of terrestrial prey in its diet in sympatry, whereas no change was observed in brook trout. Different conclusions regarding the feeding habits may, however, be influenced by different methodological approaches. Stable isotope analysis used by Cucherousset et al. (2007) reflect diet over extended time periods (Post, 2002), whereas the stomach contents analysed in our study provide short-term information. Similar to our study, Mookerji et al. (2004) found terrestrial insects to be more frequent in the diet of brook trout in sympatry with Atlantic salmon, and McHugh et al. (2008) documented higher proportions of terrestrial invertebrates in the diet of the cutthroat trout, Oncorhynchus clarkii (Richardson, 1836), living in sympatry with brown trout.

The potential ecological importance of these dietary differences could be high (McHugh et al., 2008). Terrestrial invertebrates may largely cover the energy intake of streamdwelling salmonids in summer (Sánchez-Hernández and Cobo, 2016). This reduces interspecific competitive interactions for benthic invertebrates through resource partitioning (Dineen et al., 2007), and becomes an important mechanism promoting the coexistence of related fish species (Miyasaka et al., 2003). Therefore, it is possible that the observed shift in brook trout diet from our study resulted from competitive interactions with brown trout. A dietary shift observed for one species but not the other suggests that at the studied sympatric locality, native brown trout has a competitive advantage over alien brook trout.

The feeding strategy of both fish species in our study may be characterized as mixed - fish were overall generalists with specialization on specific prey. The observed diet composition was similar to that found in previous studies on brown trout and brook trout (Fechney, 1988; Kelly-Quinn and Bracken, 1990; Sánchez-Hernández et al., 2013). Both species feed on a diverse array of invertebrates, and often consume the largest, most abundant prey (Mistak et al., 2003; Mcneale et al., 2010). In our study, brown trout preferred trichopterans and brook trout chironomids. Similarly, dipterans and terrestrial insects were more important for cutthroat trout than brown trout in coexistence (McHugh et al., 2008). In the study of Mistak et al. (2003) from a river in Michigan, both brown trout and brook trout preferred athericid and tipuliid larvae, and chironomid larvae were not selected. Obviously, such differences may reflect different food supply in study regions.

Our study offers an insight on seasonal changes in the dietary overlap in comparison with the stomach fullness data. Usually, there is a decline in percent stomach mass during the season from spring to autumn (Lagarrigue et al., 2002; Mistak et al., 2003). The pattern of seasonal decline, with total stomach volume highest in early summer and declining through August, was similar in our study, as were the values of stomach fullness, averaging $10 \%$ of body weight in fish with similar length (Mistak et al., 2003). Reports on diet overlap between two related coexisting salmonid species are scarce. McHugh et al. (2008) reported percent diet overlaps between brown and cutthroat trout of $87.5 \%$ and $89.5 \%$, which are higher values in comparison to those found in our study, where the diet overlap attained a maximum of $81.5 \%$. Low diet overlap between Atlantic salmon and rainbow trout in allopatry, but high in sympatry were found by Coghlan et al. (2007).

High diet overlap between two coexisting species may indicate that localities have sufficient resources for both species to coexist (Schoener, 1968), but also a high potential 


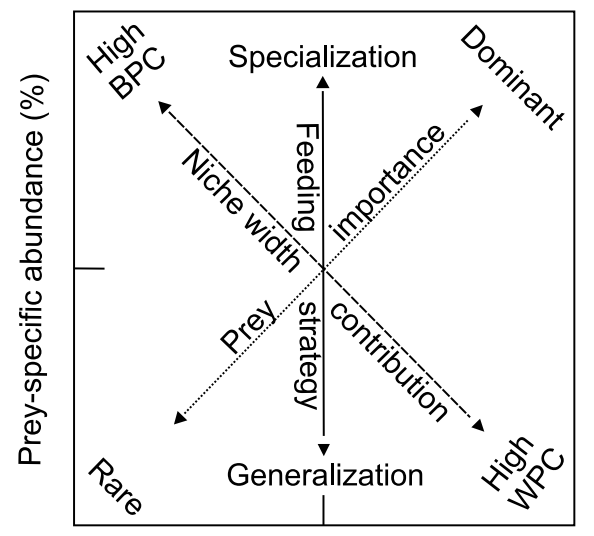

Frequency of occurrence

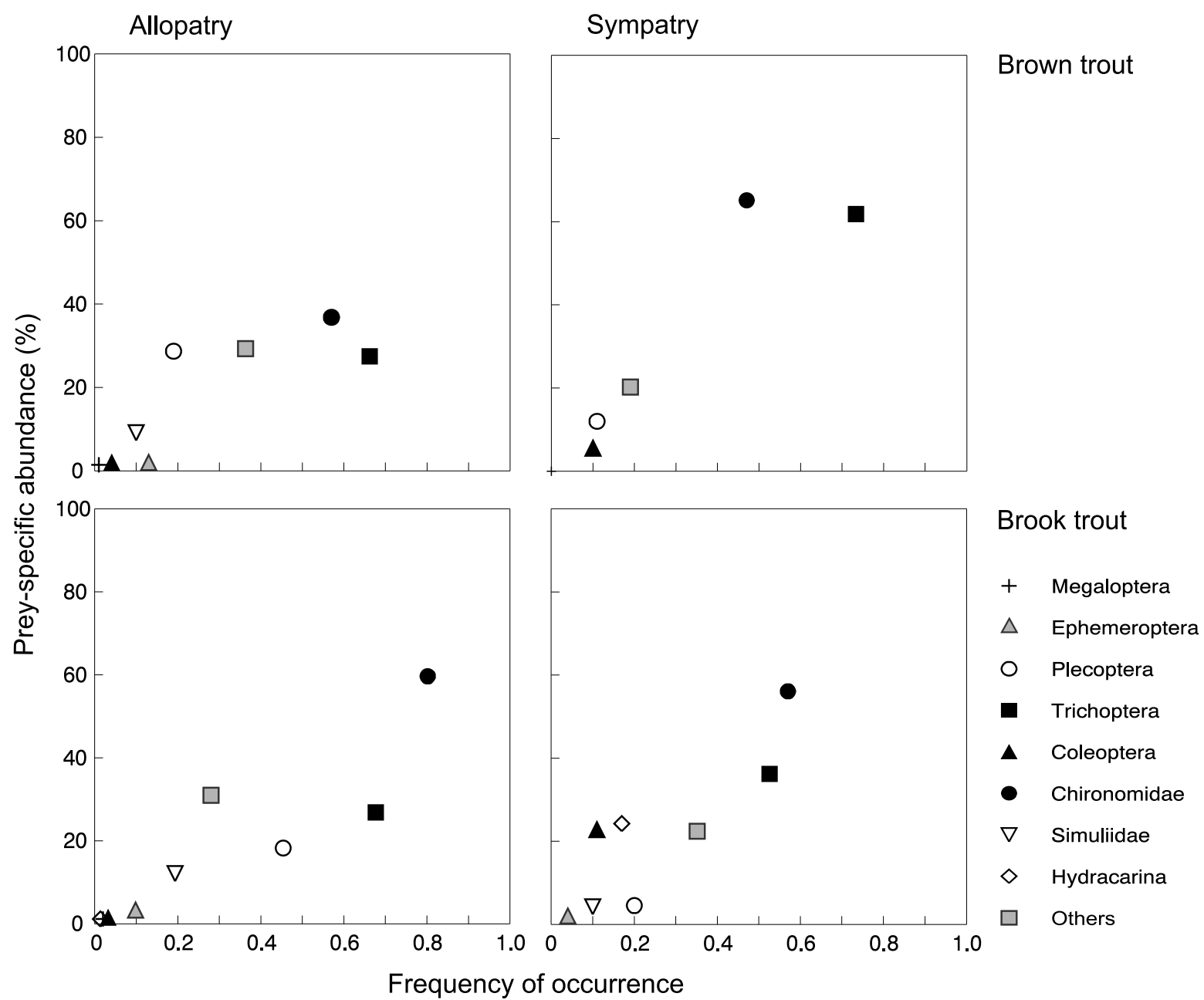

Fig. 4. Feeding tactics according to Amundsen et al. (1996). The upper panel is an explanatory diagram for interpreting feeding tactic, niche width contribution, and prey importance (adapted from Tagliaferro et al., 2015). WFC: within-phenotype component, BPC: between-phenotype component. See also Table S5.

for interspecific competition (Coghlan et al., 2007). Our results show that in the season with a high feeding intensity (reflected in high stomach fullness), there was a lower dietary overlap in comparison with the periods when feeding intensity declined. Similarly, Scrimgeour and Winterbourn (1987) found that during times of food scarcity, the diets of two sympatric stream fishes were more similar. In opposite, Nakano et al. (1999) showed that diet overlap between charr species was higher when resources were abundant. Such results corroborate that salmonids are flexible in foraging and interspecific diet 


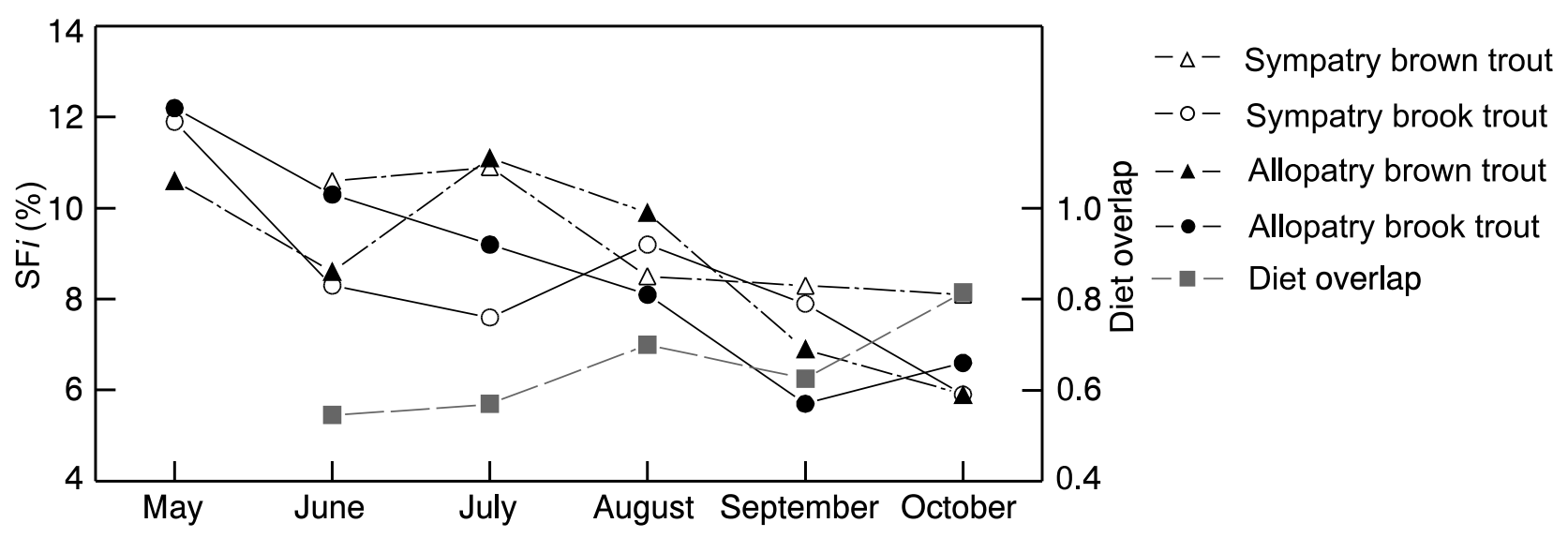

Fig. 5. Mean stomach fullness index $\left(\mathrm{SF}_{i}, \%\right)$ and diet overlap by month for all lengths of brook and brown trout sampled in Malá Jeřice (sympatry; brown trout, $n=58$; brook trout, $n=48$ ), Malý Štolpich (brown trout, $n=58$ ), and Černá Nisa (brook trout, $n=71$ ).

partitioning largely depends on temporal changes in food availability and species involved (Nakano et al., 1999; Di Prinzio and Casaux, 2012).

Observed changes in dietary overlap, together with the specialization on different prey categories, provide an evidence of dietary competition and interactive segregation, which may help the species to reduce competition (Hearn, 1987). The dietary shift observed for brook trout, but not for brown trout, suggests that brown trout may be a stronger competitor, leading the brook trout to change its feeding habits to reduce interspecific competition. Our study gives insights into the processes which may take place at localities where the species coexist. However it evaluates feeding biology of fish in particular part of the year, and for fish of a defined age category. Diet composition of fish usually change during ontogeny and within season (Nakano et al., 1999; Arismendi et al., 2012), which may influence final outcomes of interspecific interaction. Feeding habits and food resource use in fish of various ontogenetic stages and during the winter period, when a significant bottleneck in food supply may be expected, remains to be explored.

\section{Supplementary Material}

Table S1 Food supply (aquatic prey) estimated from monthly benthos samples at studied localities.

Table S2 Food supply (terrestrial prey) estimated from monthly drift samples at studied localities.

Table S3 Monthly summary of prey items found in sampled fish.

Table S4 Index of stomach fullness $\left(\% \mathrm{SF}_{i}\right)$; average values for May to October 2004. Mean percent stomach content weight of brown trout and brook trout sampled in Malá Jeřice (brown trout, $n=58$; brook trout, $n=48$ ), Malý Štolpich (brown trout; $n=58$ ) and Černá Nisa (brook trout; $n=71$ ).

Table S5 Macroinvertebrate frequency of occurrence $\left(F_{i}\right)$ and prey-specific abundance $\left(\% P_{i}\right)$ of prey in stomach contents of brown trout and brook trout; averaged values for six months (May-October).
The Supplementary Material is available at http://www. kmae-journal.org/10.1051/kmae/2016038/olm.

Acknowledgements. The research was supported by the Grant Agency of Charles University (project GAUK 232/2004 B Bio), the Ministry of Education (project MSM0021620828) and the Czech Science Foundation (no. 16-06498S). We thank anonymous reviewers for feedback on the manuscript, and Tyler J. Kohler for linguistic corrections.

\section{References}

Allan JD, Russek E. 1985. The quantification of stream drift. Can J Fish Aquat Sci 42: 210-215.

Amundsen P-A, Gabler H-M, Staldvik FJ. 1996. A new approach to graphical analysis of feeding strategy from stomach contents data - modification of the Costello (1990) method. J Fish Biol 48: 607-614.

Arismendi I, González J, Soto D, Penaluna B. 2012. Piscivory and diet overlap between two non-native fishes in southern Chilean streams. Aust Ecol 37: 346-354.

Blanchet S, Loot G, Grenouillet G, Brosse S. 2007. Competitive interactions between native and exotic salmonids: a combined field and laboratory demonstration. Ecol Freshw Fish 16: 133-143.

Coghlan S, Cain G, Ringler N. 2007. Prey selection of subyearling Atlantic salmon and rainbow trout coexisting in a natural stream. $J$ Fresh Ecol 22: 591-607.

Conrad JL, Weinersmith KL, Brodin T, Saltz JB, Sih A. 2011. Behavioural syndromes in fishes: a review with implications for ecology and fisheries management. $J$ Fish Biol 78: 395-435.

Cucherousset J, Aymes JC, Santoul F, Céréghino R. 2007. Stable isotope evidence of trophic interactions between introduced brook trout Salvelinus fontinalis and native brown trout Salmo trutta in a mountain stream of south-west France. J Fish Biol 71: 210-223.

Delacoste M, Baran P, Lascaux JM, Abad N, Besson JP. 1997. Bilan des introductions de salmonidés dans les lacs et ruisseaux d'altitude des Hautes-Pyrénées. Bull Fr Pêche Piscic 344/345: 205-219. 
Di Prinzio CY, Casaux RJ. 2012. Dietary overlap among native and non-native fish in Patagonian low-order streams. Int J Lim 48: 21-30.

Dineen G, Harrison SSC, Giller PS. 2007. Diet partitioning in sympatric Atlantic salmon and brown trout in streams with contrasting riparian vegetation. J Fish Biol 71: 17-38.

Dunham JB, Adams SB, Schroeter RE, Novinger DC. 2002. Alien invasions in aquatic ecosystems: toward an understanding of brook trout invasions and potential impacts on inland cutthroat trout in western North America. Rev Fish Biol Fish 12: 373-391.

Fausch KD, White RJ. 1981. Competition between Brook trout (Salvelinus fontinalis) and Brown trout (Salmo trutta) for positions in a Michigan stream. Can J Fish Aquat Sci 38: 1220-1227.

Fechney LR. 1988. The summer diet of brook trout (Salvelinus fontinalis) in a South Island high-country stream. $N Z J$ Mar Fresh Res 22: 163-168.

Finlayson B, Somer W, Duffield D, et al. 2005. Native inland trout restoration on national forests in the western United States: time for improvement? Fisheries 30: 10-19.

Frost S. 1971. Evaluation of kicking technique for sampling stream bottom fauna. Can J Zool 49: 167-173.

Hearn WE. 1987. Interspecific competition and habitat segregation among stream dwelling trout and salmon: a review. Fisheries 12: $24-31$.

Holčík J. 1991. Fish introductions in Europe with particular reference to its central and eastern part. Can J Fish Aquat Sci 48: $13-23$.

Jacobs J. 1974. Quantitative measurement of food selection. A modification of the forage ratio and Ivlev's electivity index. Oecologia 14: 413-417.

Kelly-Quinn M, Bracken JJ. 1990. A seasonal analysis of the diet and feeding dynamics of brown trout, Salmo trutta L., in a small nursery stream. Aquacult Res 21: 107-124.

Kenward MG, Roger JH. 1997. Small sample inference for fixed effects from restricted maximum likelihood. Biometrics 53: 983-997.

Kitano S, Maekawa K, Nakano S, Fausch KD. 1994. Spawning behaviour of bull trout in the Upper Flathead Drainage, Montana, with special reference to hybridization with brook charr. Trans Am Fish Soc 123: 988-992.

Lagarrigue T, Céréghino R, Lim P, Reyes-Marchant P, Chappaz R, Lavandier P, Belaud A. 2002. Diel and seasonal variation in brown trout (Salmo trutta) feeding patterns and relationship with invertebrate drift under natural and hydropeaking conditions in a mountain stream. Aquat Living Resour 15: 129-137.

Langton RW. 1982. Diet overlap between Atlantic cod, Gadus morhua, silver hake, Merluccius bilinearis, and fifteen other North-west Atlantic finfish. Fish Bull US 80: 745-759.

Littell RC, Milliken GA, Stroup WW, Wolfinger RD. 1996. SAS System for Mixed Models. Cary, NC: SAS Institute Inc.

Lusk S, Lusková V, Hanel L. 2010. Alien fish species in the Czech Republic and their impact on the native fish fauna. Folia Zool 59: 57-72.

McHugh P, Budy P, Thiede G, VanDyke E. 2008. Trophic relationships of nonnative brown trout, Salmo trutta, and native Bonneville cutthroat trout, Oncorhynchus clarkii utah, in a northern Utah, USA river. Environ Biol Fish 81: 63-75.

Mcneale KH, Sanderson BL, Courbois J-YP, Kiffney PM. 2010. Effect of non-native brook trout (Salvelinus fontinalis) on threatened juvenile Chinook salmon (Oncorhynchus tshawytscha) in an Idaho stream. Ecol Freshw Fish 19: 139-152.
Mistak JL, Hayes DB, Bremigan MT. 2003. Food habits of coexisting salmonines above and below Stronach Dam in the Pine River, Michigan. Environ Biol Fish 67: 179-190.

Miyasaka H, Nakano S, Furukawa-Tanaka T. 2003. Food habit divergence between white-spotted charr and masu salmon in Japanese mountain streams: circumstantial evidence for competition. Limnology 4: 1-10.

Mookerji N, Weng Z, Mazumder A. 2004. Food partitioning between coexisting Atlantic salmon and brook trout in the Sainte-Marguerite River ecosystem, Quebec. J Fish Biol 64: 680-694.

Morgan DL, Gill HS, Maddern MG, Beaty SJ. 2004. Distribution and impact of introduced freshwater fishes in Western Australia. N Z J Mar Fresh Res 38: 511-523.

Nakano S, Kitano S, Nakai K, Fausch KD. 1998. Competitive interactions for foraging microhabitat among introduced brook charr, Salvelinus fontinalis, and native bull charr, S. confluentus, and westslope cutthroat trout, Oncorhynchus clarki lewisi, in a Montana stream. Environ Biol Fish 52: 345-355.

Nakano S, Fausch KD, Kitano S. 1999. Flexible niche partitioning via a foraging mode shift: a proposed mechanism for coexistence in stream-dwelling charrs. J Anim Ecol 68: 1079-1092.

Peterson DP, Fausch KD. 2003. Upstream movement by nonnative brook trout (Salvelinus fontinalis) promotes invasion of native cutthroat trout (Oncorhynchus clarki) habitat. Can J Fish Aquat Sci 60: $1502-1516$.

Pianka ER. 1969. Sympatry of desert lizards (Ctenotus) in Western Australia. Ecology 50: 1012-1030.

Post MD. 2002. Using stable isotopes to estimate trophic position: models, methods, and assumptions. Ecology 83: 703-718.

Sánchez-Hernández J, Cobo F. 2016. Ontogenetic shifts in terrestrial reliance of stream-dwelling brown trout. J Limnol 75: 409-414.

Sánchez-Hernández J, Servia MJ, Vieira-Lanero R, Cobo F. 2013. Prey trait analysis shows differences in summer feeding habitat use between wild YOY Atlantic salmon and brown trout. Ital J Zool 80: 449-454.

Sánchez-Hernández J, Gabler H-M, Amundsen P-A. 2016. Food resource partitioning between stream-dwelling Arctic charr Salvelinus alpinus (L.), Atlantic salmon Salmo salar L. and alpine bullhead Cottus poecilopus Heckel, 1836: an example of water column segregation. Hydrobiologia 783: 105-115.

Schoener TW. 1968. The anolis lizards of Bimini: resource partitioning in a complex fauna. Ecology 49: 704-726.

Schoener TW. 1970. Non-synchronous spatial overlap of lizards in patchy habitats. Ecology 51: 408-418.

Schoener TW. 1974. Resource partitioning in ecological communities. Science 185: 27-39.

Scrimgeour GJ, Winterbourn MJ. 1987. Diet, food resource partitioning and feeding periodicity of two riffle dwelling fish species in a New Zealand river. J Fish Biol 31: 309-324.

Seber GAF, Le Cren ED. 1967. Estimating population parameters from catches large relative to the population. J Anim Ecol 36: 631-643.

Tagliaferro M, Arismendi I, Lancelotti J, Pascual M. 2015. A natural experiment of dietary overlap between introduced rainbow trout (Oncorhynchus mykiss) and native Puyen (Galaxias maculatus) in the Santa Cruz River, Patagonia. Environ Biol Fish 98: 1311-1325.

Takami T, Aoyama T. 1999. Distributions of rainbow trout and brown trout in Hokkaido northern Japan. Wildl Conserv Jpn 4: 41-48.

Taniguchi Y, Fausch KD, Nakano S. 2002. Size-structured interactions between native and introduced species: can intraguild predation facilitate invasion by stream salmonids? Biol Inv 4: 223-233. 
P. Horká et al.: Knowl. Manag. Aquat. Ecosyst. 2017, 418, 6

Tiberti R, Brighenti S, Canedoli C, Iacobuzio R, Rolla M. 2016. The diet of introduced brook trout (Salvelinus fontinalis; Mitchill, 1814) in an alpine area and a literature review on its feeding ecology. J Limnol 75: 488-507.

Uiblein F, Jagsch A, Honsig-Erlenburg W, Weis S. 2001. Status, habitat use, and vulnerability of the European grayling in Austrian waters. J Fish Biol 59: 223-224.
Wilson MK, Lowe WH, Nislow KH. 2014. What predicts the use by brook trout (Salvelinus fontinalis) of terrestrial invertebrate subsidies in headwater streams? Freshw Biol 59: 187-199.

Woodford DJ, Impson ND, Day JA, Bills IR. 2005. The predatory impact of invasive alien smallmouth bass, Micropterus dolomieu (Teleostei: Centrarchidae), on indigenous fishes in a Cape Floristic Region mountain stream. Afr J Aquat Sci 30: 167-173.

Cite this article as: Horká P, Sychrová O, Horký P, Slavík O, Švátora M, Petrusek A. 2017. Feeding habits of the alien brook trout Salvelinus fontinalis and the native brown trout Salmo trutta in Czech mountain streams. Knowl. Manag. Aquat. Ecosyst., 418, 6. 